\section{A Survey of Water and Fertilizer Management During Cutting Propagation}

\author{
Kathryn M. Santos ${ }^{1,3}$, Paul R. Fisher ${ }^{1}$, and William R. Argo ${ }^{2}$
}

ADDITIONAL INDEX WORDs. calibrachoa, greenhouse, leaching, nitrogen nutrient distribution, petunia, phosphorus, potassium, uptake efficiency, vegetative cuttings

SUMMARY. The objective of this study was to quantify water volume and nutrient content leached during propagation of herbaceous cuttings in commercial greenhouses. Nutrient concentrations in the fertigation solution, substrate, tissue, and leachate were measured between Jan. and Mar. 2006 at eight greenhouse locations in Michigan, Colorado, New Hampshire, and New Jersey. Grower management of the timing and concentration of nutrients applied to vegetatively grown calibrachoa (Calibrachoa $\times$ bybrida) or petunia $($ Petunia $\times$ bybrida) liner trays varied among the eight locations, ranging from 0.5 to $80 \mathrm{mg} \cdot \mathrm{L}^{-1}$ nitrogen $(\mathrm{N})$ in week 1 and from 64 to $158 \mathrm{mg} \cdot \mathrm{L}^{-1} \mathrm{~N}$ in week 4. Over a 4-week crop period, applied nutrients averaged $4.9 \mathrm{~g} \cdot \mathrm{m}^{-2} \mathrm{~N}, 0.8 \mathrm{~g} \cdot \mathrm{m}^{-2}$ phosphorus $(\mathrm{P})$, and $5.8 \mathrm{~g} \cdot \mathrm{m}^{-2}$ potassium $(\mathrm{K})$, and leached nutrients averaged $1.1 \mathrm{~g} \cdot \mathrm{m}^{-2} \mathrm{~N}, 0.3 \mathrm{~g} \cdot \mathrm{m}^{-2} \mathrm{P}$, and $1.6 \mathrm{~g} \cdot \mathrm{m}^{-2} \mathrm{~K}$. Leaching of nutrients and irrigation water was highly variable among locations. Leached water volumes ranged from 4.5 to $46.1 \mathrm{~L} \cdot \mathrm{m}^{-2}$ over 4 weeks and contained 0.29 to $1.81 \mathrm{~g} \cdot \mathrm{m}^{-2} \mathrm{~N}, 0.11$ to $0.45 \mathrm{~g} \cdot \mathrm{m}^{-2} \mathrm{P}$, and 0.76 to $2.86 \mathrm{~g} \cdot \mathrm{m}^{-2} \mathrm{~K}$. The broad range in current commercial fertigation practices, including timing of nutrient supply, concentration of applied fertilizer, and leaching volume, indicate considerable potential to improve efficiency of water and fertilization resources during propagation and reduce runoff.

$\mathrm{M}$ ost horticultural production firms either propagate or buy seed, cuttings, or tissue-cultured propagules. These propagules are planted into small cells called plugs or liners, placed under high humidity to germinate or produce roots, and are subsequently grown to a saleable seedling plug or rooted liner, which requires 4 to 6 weeks in the case of most herbaceous cuttings. The plug or liner is then transplanted into the field or landscape or into a larger container for further growth before sale. The total value of sales of propagative plant material for cut flowers, potted flowering plants, annual bedding and garden plants, herbaceous perennials, foliage, and cut cultivated greens for 2005 was $\$ 439$ million, $2 \%$ above the previous year (U.S. Dept. Agr., 2006). Annual bedding and garden plants accounted for $49 \%$ of all propagative material, or \$214 million. These propagation numbers probably underestimate the economic value of the seedling and cutting industry

${ }^{1}$ Department of Environmental Horticulture, University of Florida, 1539 Fifield Hall, P.O. Box 110670 , Gainesville, FL 32611

${ }^{2}$ Blackmore Company, 10800 Blackmore Avenue, Belleville, MI 48111

${ }^{3}$ Corresponding author. E-mail: kmsantos@ufl.edu. when including vegetable, woody ornamental, and fruit production.

Agriculture accounts for over $80 \%$ of freshwater consumption in the United States and an increase in water use regulations necessitates improved irrigation strategies (Weibe and Gollehon, 2006). Greenhouse propagation involves considerable application of water for control of humidity, soil moisture, and as a means to apply water-soluble fertilizer. In a typical rooting environment for vegetative cuttings, water is initially supplied by either mist emitters or automated boom watering systems to minimize transpiration loss. The amount of water required is species-dependent. For example, artemisia (Artemesia spp.), gaura (Gaura lindheimeri), rosemary (Rosemarinus officinalis), or lavender (Lavandula angustifolia) cuttings rooting performance is reduced in high-mist environments (Dole and Gibson, 2006). Excessive water application can lead to increased use of water resources and associated production costs, reduce oxygen availability in the substrate, and thereby reduce rooting percentage (Geneve et al., 2004). Improved irrigation management may help reduce nutrient, pesticide, and trace element loads in irrigation runoff to surface waters as well as leaching of agricultural chemicals into groundwater supplies (Schaible and Aillery, 2003).

Annual nitrogen (N) fertilizer application rates as high as $3600 \mathrm{~kg} \cdot \mathrm{ha}^{-1}$ $\mathrm{N}$ were estimated for chrysanthemum (Dendranthema xgrandiflorum) (Nelson, 1998) and poinsettia (Euphorbia pulcherrima) potted crops (Yelanich and Biernbaum, 1994). Much of the excess $\mathrm{N}$ applied in crops grown with high fertilizer concentrations and heavy leaching can be lost into the environment, depositing as much as $100 \mathrm{mg}$ of nitrate-nitrogen $\left(\mathrm{NO}_{3}-\mathrm{N}\right)(243 \mathrm{~mL}$ or of effluent with a $\mathrm{NO}_{3}-\mathrm{N}$ concentration of 411.6 $\left.\mathrm{mg} \cdot \mathrm{L}^{-1}\right)$ per irrigation from a 6 -inchdiameter pot into the soil profile (McAvoy et al., 1992). Soluble phosphate and micronutrients are also used more intensively per hectare in greenhouse

\begin{tabular}{clll}
\hline $\begin{array}{l}\text { Units } \\
\text { To convert U.S. to SI, } \\
\text { multiply by }\end{array}$ & U.S unit & SI unit & $\begin{array}{l}\text { To convert SI to U.S., } \\
\text { multiply by }\end{array}$ \\
\hline 0.4047 & $\mathrm{acre}(\mathrm{s})$ & $\mathrm{ha}$ & 2.4711 \\
29.5735 & $\mathrm{fl} \mathrm{oz}$ & $\mathrm{mL}$ & 0.0338 \\
0.0929 & $\mathrm{ft}{ }^{2}$ & $\mathrm{~m}^{2}$ & 10.7639 \\
3.7854 & $\mathrm{gal}$ & $\mathrm{L}$ & 0.2642 \\
9.3540 & $\mathrm{gal} / \mathrm{acre}$ & $\mathrm{L} \cdot \mathrm{ha}^{-1}$ & 0.1069 \\
40.7458 & $\mathrm{gal} / \mathrm{ft}^{2}$ & $\mathrm{~L} \cdot \mathrm{m}^{-2}$ & 0.0245 \\
2.54 & inch $(\mathrm{es})$ & $\mathrm{cm}$ & 0.3937 \\
6.4516 & inch & $\mathrm{cm}$ & 0.1550 \\
1.1209 & lb/acre & $\mathrm{kg} \cdot \mathrm{ha}^{-1}$ & 0.8922 \\
1 & $\mathrm{mmho} / \mathrm{cm}$ & $\mathrm{dS} \cdot \mathrm{m}^{-1}$ & 1 \\
28.3495 & $\mathrm{oz}$ & $\mathrm{g}$ & 0.0353 \\
28,350 & $\mathrm{oz}$ & $\mathrm{mg}$ & $3.5274 \times 10^{-5}$ \\
305.1517 & $\mathrm{oz} / \mathrm{ft}^{2}$ & $\mathrm{~g} \cdot \mathrm{m}^{-2}$ & 0.0033 \\
7.4892 & $\mathrm{oz} / \mathrm{gal}$ & $\mathrm{g} \cdot \mathrm{L}^{-1}$ & 0.1335 \\
0.001 & $\mathrm{ppm}$ & $\mathrm{g} \cdot \mathrm{L}^{-1}$ & 1000 \\
1 & $\mathrm{ppm}$ & $\mathrm{mg} \cdot \mathrm{L}^{-1}$ & 1 \\
$\left({ }^{\circ} \mathrm{F}-32\right) \div 1.8$ & ${ }^{\circ} \mathrm{F}$ & ${ }^{\circ} \mathrm{C}$ & $\left(1.8 \times{ }^{\circ} \mathrm{C}\right)+32$ \\
& & &
\end{tabular}


production than in field crop production (Nelson, 1990).

A similar net nutrient supply can be achieved with either low fertilizer and leaching rates (resource-efficient strategy) or high fertilizer and leaching rates (resource-inefficient); and commercial horticultural practices vary widely (Yelanich and Biernbaum, 1993). Fertilizers applied to both stock plants and during propagation of cuttings impact successful rooting of vegetative cuttings in propagation (Blazich, 1988; Gibson, 2003; Lebude et al., 2004; Rowe and Blazich, 1999). Biernbaum et al. (1995) and Kerr and Hanan (1985) found that the majority of fertilizer salts were rapidly removed from container media after leaching of one container capacity (Biernbaum et al., 1995) or one soil volume (Kerr and Hanan, 1985). Container capacity can be defined as the total amount of water present in the container after the substrate is saturated and then allowed to drain for $1 \mathrm{~h}$.

Previous research on leaching in greenhouses (Groves et al., 1998; $\mathrm{Ku}$ and Hershey, 1997; Argo and Biernbaum, 1996; Yelanich and Biernbaum, 1994) has focused on potted plants rather than propagation. We are unaware of research on leaching and fertilizer concentration in plug and liner trays in which the water inputs relative to substrate volume may be much higher than in large containers. Based on the variability in growing practices within the industry, management practices need to be evaluated and critical areas such as the amount of water and nutrients lost should be quantified to determine points of potential improvement. Our objectives were to: 1) quantify levels of irrigation water leached during production of liner trays in multiple commercial greenhouse operations; 2) quantify nutrient levels in substrate, tissue, and leachate of these commercial crops; and 3) compare nutrient use efficiency at each location.

\section{Materials and methods}

Nutrient and irrigation data were collected in 2006 from eight greenhouse locations in Michigan, Colorado, New Hampshire, and New Jersey, which represent a range in climatic conditions within the northern United States. Two greenhouse locations were selected in each of four states, each of which had at least 3 ha in plug and liner production. Each greenhouse location represented an experimental unit. Although several locations had the capability to recirculate irrigation water, none were doing so with these crops because of disease susceptibility. The greenhouse businesses were leading propagators that had previously cooperated with the authors in on-site trials, and we were therefore confident about being able to collect reliable data. The timing for the experiments was determined based on the peak production season for U.S. propagation of annuals (January to March). The experiment was run for 1 week at each location (conditions described in Table 1) and four crops of vegetatively grown liner trays were related that were either 0 to 1,1 to 2,2 to 3 , or 3 to 4 weeks of age. In this context, a "crop" refers to a specific age group in one location. In six locations, calibrachoa was selected; and in two locations, petunia was selected. Species selection depended on the crops grown and available at each location, and both species had a similar 4- to 5week crop time in a liner tray (Blackmore Co., Belleville, MI). The cultivar within the species was consistent within a given location, but varied between locations.

Within each crop, there were five replicate measurements of each of the following variables located randomly within the crop: volume, $\mathrm{pH}$ (Pinnacle Corning $\mathrm{pH}$ Meter model 430; Nova Analytics Corp., Woburn, MA) and electrical conductivity (EC) (Orion model 130; Thermo Fisher Scientific, Waltham, MA) of applied nutrient solution $(\mathrm{n}=$ 5) (using five individual irrigation collection funnels); volume, $\mathrm{pH}$, and EC of leached nutrient solution (using five leachate collection trays); substrate-pH and substrate-EC (using five liner propagation trays); and plant fresh and dry weights (combined root and shoot using five groups of three plants each). Within each crop, there was a single replicate measurement of each of the following: substrate nutrient levels (combined from five trays), leachate nutrient levels $(\mathrm{n}=\mathrm{l})$ (combined from five leachate samples), tissue nutrient levels (from 15 combined plants), and tissue nutrient levels on unrooted ("week 0") plants.
Data were analyzed as a split plot design with location as the main plot, crop age as the subplot, and each tray as a random block. There were no significant differences between species or cultivar; therefore, location was assigned as the main factor in the model. Proc Mixed and Proc GLM in SAS (version 9.1; SAS Institute, Cary, NC) were used for statistical analysis and Tukey's honestly significant difference test was used for mean comparisons.

\section{Quantify leached irrigation water volume}

Growers recorded the number and schedule of irrigation events per day, N:P:K ratio, and concentration (parts per million) of fertilizer applied. The volume of applied irrigation solution was measured by randomly placing five "irrigation collection funnels" (0.47-L dark brown plastic bottles topped with open funnels, surface area $=24.4 \mathrm{~cm}^{2}$ and stood $17 \mathrm{~cm}$ above the bottle) in each of the four crops, or a total of 20 bottles (five bottles/crop $\times$ four crops) per location. The irrigation collection funnels were left for 1 week, and growers were instructed to apply irrigation solution evenly across the crop surface and funnels as per normal practices. The data for irrigation water volume applied were not shown as a result of too much variability in the measurements.

The volume of solution leached from the propagation trays was measured by placing $2015 \times 45-\mathrm{cm}$ "leachate collection trays" beneath five propagation trays per crop. The vent holes on the top of plug trays (in between the plug cells) were covered with water-resistant tape to prevent irrigation water from running directly into the leachate collecting tray. After l week, the collection trays were removed from beneath the propagation trays and the leachate volumes were measured.

\section{Quantify nutrient levels in tissue, substrate, and leachate}

From each of the five replicate samples per crop, $25 \mathrm{~mL}$ of applied irrigation water (from the irrigation collection funnels) and leachate (from the leachate collection trays) were collected. The $\mathrm{pH}$ and EC were recorded for each of those samples. The five samples from each crop were 


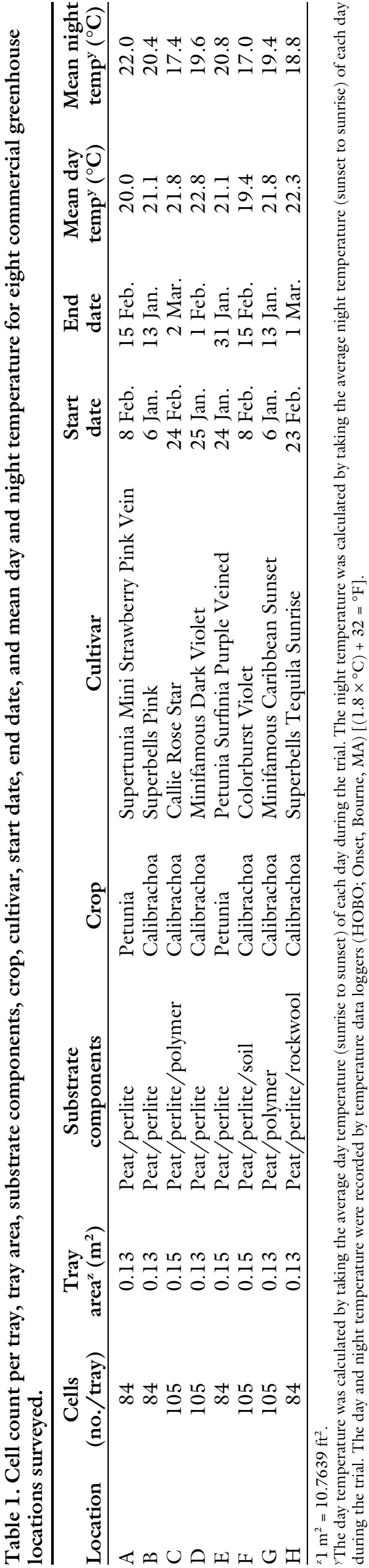

then combined into one sample per crop and sent to Quality Analytical Laboratories (Panama City, FL) for a complete nutrient analysis using inductively coupled plasma atomic emission spectrophotometry (ICAP 61E; Thermo-Jarrell Ash, Franklin, $\mathrm{MA})$ to measure $\mathrm{P}, \mathrm{K}$, calcium (Ca), magnesium $(\mathrm{Mg})$, sulfur $(\mathrm{S})$, iron $(\mathrm{Fe})$, manganese $(\mathrm{Mn})$, boron $(\mathrm{B})$, copper $(\mathrm{Cu})$, zinc $(\mathrm{Zn})$, molybdenum (Mo), aluminum, and sodium. The leachate and substrate solution samples were analyzed for $\mathrm{NO}_{3}-\mathrm{N}$ and ammonium $\left(\mathrm{NH}_{4}\right) \mathrm{N}$ using a Lachat QuikChem AE (Lachat Instruments, Loveland, CO). This instrument uses flow injection analysis to colorimetrically determine $\mathrm{NO}_{3}-\mathrm{N}$ and $\mathrm{NH}_{4}-\mathrm{N}$ concentration. For tissue samples, $\mathrm{N}$ was measured as total Kjeldahl $\mathrm{N}$ where all the protein is converted to $\mathrm{NH}_{4}$ using heat, a catalyst, sulfuric acid, and hydrogen peroxide. The sample was then run on a spectrophotometer (DR 4000; Hach, Loveland, $\mathrm{CO}$ ) using Nesslerization for $\mathrm{N}$ determination. A Hach Digestahl apparatus was used for the conversion (digestion) and a spectrophotometer (DR 4000) for the analysis.

Plug squeeze tests were performed $\approx \mathrm{l} h$ after irrigation with nutrient solution by pressing down firmly on the top of the substrate surface and collecting the solution from the hole at the bottom of the pressed plug cell on each of the five replicate propagation trays per crop (Scoggins et al., 2002). The $\mathrm{pH}$ and EC were recorded individually for these samples.

The plug squeeze samples were then combined into a single replicate per crop for complete nutrient analysis. Five groups of three plants were removed from random locations within trays in each crop. The plants were washed in four separate baths of deionized water to remove any substrate from the root mass and to clean the foliage. Fresh weight of each replicate sample of three combined plants was taken, placed in a forced-air drying oven at $55{ }^{\circ} \mathrm{C}$, and weighed again after all liquids evaporated $(3 \mathrm{~d})$ to measure dry weight. The dry tissue samples were combined by crop for a complete nutrient analysis. The container capacity (CC) was calculated for substrates at each location by measuring the total amount of water present in the container after the substrate has been saturated using subirrigation and allowed to drain for $\approx \mathrm{l} h$.

\section{Compare nutrient use efficiency at each location}

The resource use for each location was calculated using the following formulae:

Tissue nutrient uptake $=[($ final $\mathrm{DW}$ in $\left.\mathrm{g} \cdot \mathrm{m}^{-2}\right) \times($ final tissue $\% \mathrm{~N}$, $\mathrm{P}$, or $\mathrm{K})]-\left[\left(\right.\right.$ initial $\mathrm{DW}$ in $\left.\mathrm{g} \cdot \mathrm{m}^{-2}\right)$ $\times($ initial tissue $\% \mathrm{~N}, \mathrm{P}$, or $\mathrm{K})]$, where DW = dry weight. [1]

Final nutrient concentration in substrate $=\left(\mathrm{CC}\right.$ in $\left.\mathrm{L} \cdot \mathrm{m}^{-2}\right) \times($ final concentration $\mathrm{N}, \mathrm{P}$, or $\mathrm{K}$ in $\left.\mathrm{g} \cdot \mathrm{L}^{-1}\right) \cdot[2]$

Total nutrient leached $=$ total leachate volume in liters $\times$ total concentration $\mathrm{N}, \mathrm{P}$, or $\mathrm{K}$ in $\left.\mathrm{g} \cdot \mathrm{L}^{-1}\right) \cdot[3]$

$\% \mathrm{~N}$ distribution $=[(\mathrm{A}) /($ leachate $\mathrm{N}$ in grams + tissue uptake $\mathrm{N}$ in grams + final substrate $\mathrm{N}$ in grams) $] \times 100$, where $\mathrm{A}=$ leachate $\mathrm{N}$, tissue nutrient $\mathrm{N}$, or final substrate $\mathrm{N}(\mathrm{Ku}$ and Hershey, 1997). [4]

\section{Results and discussion Quantify leached irrigation water volume}

The volume leached varied between locations, ranging from 0.6 to $6.0 \mathrm{~L}$ per propagation tray, which corresponded to 44,900 to 460,769 $\mathrm{L} \cdot \mathrm{ha}^{-1}$ over a 4 -week crop period (Table 2). Six of the eight locations leached at least one CC over the 4week crop cycle, and three locations leached 2.0 to 4.7 CC (Table 2). The greatest leaching also occurred during weeks 1 or 2 in six of the eight locations, and on average, significantly more water was leached during week 1 than in the subsequent 3 crop weeks (Table 3 ). The nature of vegetative propagation requires higher volumes of water to be applied to maintain humidity and plant turgidity until root formation. No previous research exists to provide a baseline to compare against; however, among these eight operations, we discovered less leaching at some indicating an excess at others. Given the rapid leaching of nutrients from soilless substrates after leaching of one CC (Biernbaum et al., 1995; Kerr and Hanan, 1985), a significant amount of preplant nutrients would have been 
Table 2. Water leached by location over a 4-week crop cycle ${ }^{\mathrm{z}}$.

\begin{tabular}{|c|c|c|c|c|}
\hline Location & $\begin{array}{c}\text { Vol } \\
\text { leached }^{\mathrm{y}} \\
\left(\mathrm{L} \cdot \mathbf{m}^{-2}\right)\end{array}$ & $\begin{array}{c}\text { Vol } \\
\text { leached }^{\mathrm{x}} \\
\left(\mathrm{L} \cdot \mathrm{ha}^{-1}\right)\end{array}$ & $\begin{array}{c}\mathrm{CC}^{\mathrm{w}} \\
\left(\mathrm{L} \cdot \mathbf{m}^{-2}\right)\end{array}$ & $\begin{array}{c}\mathrm{CC} \\
\text { leached }^{\mathrm{v}} \\
\left(\mathrm{L} \cdot \mathrm{m}^{-2} \text { per } 4 \mathrm{wk}\right)\end{array}$ \\
\hline A & $7.7 \mathrm{~cd}^{\mathrm{v}}$ & 77,215 & 9.8 & 0.8 \\
\hline B & $46.1 \mathrm{a}$ & 460,769 & 9.8 & 4.7 \\
\hline $\mathrm{C}$ & $14.2 \mathrm{~b}$ & 141,686 & 10.5 & 1.3 \\
\hline $\mathrm{D}$ & $4.5 \mathrm{~d}$ & 44,900 & 11.8 & 0.4 \\
\hline $\mathrm{E}$ & $8.7 \mathrm{bcd}$ & 87,333 & 8.6 & 1.0 \\
\hline $\mathrm{F}$ & $13.7 \mathrm{~b}$ & 136,667 & 10.6 & 1.3 \\
\hline G & $14.7 \mathrm{bc}$ & 147,184 & 6.8 & 2.2 \\
\hline$\underline{\mathrm{H}}$ & $19.5 \mathrm{~b}$ & 194,615 & 9.7 & 2.0 \\
\hline Avg & 16.1 & 161,296 & 9.7 & 1.7 \\
\hline SD & 12.1 & 121,487 & 1.4 & 1.3 \\
\hline
\end{tabular}

${ }^{\mathrm{z}}$ Leachate is quantified in terms of volume leached per tray, per hectare, or container capacities (CC) leached per tray.

${ }^{\mathrm{y}} 1 \mathrm{~L} \cdot \mathrm{m}^{-2}=0.0245 \mathrm{gal} / \mathrm{ft}^{2}$.

${ }^{\mathrm{x}} \mathrm{l} \mathrm{L} \cdot \mathrm{ha}^{-1}=0.1069 \mathrm{gal} /$ acre.

"One CC was defined as the total amount of water present in the container after the substrate was saturated and then allowed to drain for $\mathrm{l} \mathrm{h}$.

"Mean separation used Tukey's honestly significant difference test at $P \leq 0.05$.

leached early in the crop cycle before roots emerged and nutrients were taken up by the cuttings. These results indicate that irrigation volume was excessive at the beginning of the crop cycle when plant uptake would be reduced because of small leaf area and lack of plant roots.

\section{Quantify nutrient levels in nutrient solution, tissue, substrate, and leachate}

Applied nUtrients. Fertilizer strategy varied widely among locations. Applied nutrient concentrations increased with crop age as measured with both EC and N level of the applied solution (Table 3 ). On average, 24, 85, 93, and $101 \mathrm{mg} \cdot \mathrm{L}^{-1}$ $\mathrm{N}$ were applied during weeks 1 to 4 , respectively, with a nutrient solution EC of $0.44,0.88,0.87$, and 1.01 $\mathrm{dS} \cdot \mathrm{m}^{-1}$ (Table 3 ). Averaged across the 4 weeks, the nutrient concentrations in $\mathrm{mg} \cdot \mathrm{L}^{-1}$ were $76 \mathrm{~N}, 4 \mathrm{P}, 65 \mathrm{~K}$, $61 \mathrm{Ca}, 17 \mathrm{Mg}, 21 \mathrm{~S}, 2 \mathrm{Fe}, 0.4 \mathrm{Mn}$, $0.2 \mathrm{~B}, 0.3 \mathrm{Cu}, 0.4 \mathrm{Zn}$, and $0.05 \mathrm{Mo}$. Locations varied greatly in the applied $\mathrm{N}$ levels, particularly during the first 2 weeks (week 0 to $\mathrm{l}=0$ to $80 \mathrm{mg} \cdot \mathrm{L}^{-1}$ $\mathrm{N}$, week 1 to $2=0$ to $195 \mathrm{mg} \cdot \mathrm{L}^{-1} \mathrm{~N}$, week 2 to $3=19$ to $148 \mathrm{mg} \cdot \mathrm{L}^{-1} \mathrm{~N}$, and week 3 to $4=64$ to $158 \mathrm{mg} \cdot \mathrm{L}^{-1}$ N) (Table 3).

The total applied $\mathrm{N}, \mathrm{P}$, and $\mathrm{K}$ (sum of tissue uptake, nutrients leached, and final substrate nutrient content) during the 4-week crop cycle ranged by a factor of approximately four among locations, from 1.4 to $8.3 \mathrm{~g} \cdot \mathrm{m}^{-2} \mathrm{~N}, 0.3$ to $1.2 \mathrm{~g} \cdot \mathrm{m}^{-2}$
$\mathrm{P}$, and 2.7 to $10.1 \mathrm{~g} \cdot \mathrm{m}^{-2} \mathrm{~K}$ (Table 4 ), which represented 14 to $83 \mathrm{~kg} \cdot \mathrm{ha}^{-1}$ $\mathrm{N}, 3$ to $12 \mathrm{~kg} \cdot \mathrm{ha}^{-1} \mathrm{P}$, and 27 to $10 \mathrm{l}$ $\mathrm{kg} \cdot \mathrm{ha}^{-1} \mathrm{~K}$ (Table 5). On an annual basis, the applied $\mathrm{N}$ level (averaging $637 \mathrm{~kg} \cdot \mathrm{ha}^{-1} \mathrm{~N}$ ) was lower than the rate reported for potted chrysanthemum and poinsettia (Nelson, 1998; Yelanich and Biernbaum, 1994).

Tissue uptake. Tissue uptake ranged from 0.9 to $4.5 \mathrm{~g} \cdot \mathrm{m}^{-2} \mathrm{~N}, 0.2$ to $0.6 \mathrm{~g} \cdot \mathrm{m}^{-2} \mathrm{P}$, and 1.5 to $4.6 \mathrm{~g} \cdot \mathrm{m}^{-2} \mathrm{~K}$ (Table 4), varying by a factor of 3 to 4 among locations. This range was partly the result of differences in dry weight $(0.072$ to $0.177 \mathrm{~g}$ per cutting), but principally caused by differences in tissue $\mathrm{N}$ concentration among locations. The change in cutting dry weight (DW) was calculated by subtracting the final tissue DW from the tissue DW at day 0 (the date of transplanting cuttings) (Table 4). Tissue percent $\mathrm{N}$ decreased from week 0 to week 4 (Table 4 ), but there was no significant change in $\mathrm{P}$ or $\mathrm{K}$ level. In an unpublished survey of tissue nutrient levels in visually healthy unrooted cuttings, we surveyed tissue from 291 petunia and 179 calibrachoa crops from 14 commercial locations. The mean \pm 2 sDs were $3.8 \%$ to $7.5 \% \mathrm{~N}, 0.3 \%$ to $0.9 \% \mathrm{P}$, and $3.4 \%$ to $6.6 \% \mathrm{~K}$ in petunia or $3.4 \%$ to $6.3 \% \mathrm{~N}, 0.2 \%$ to $0.7 \% \mathrm{P}$, and $2.0 \%$ to $4.6 \% \mathrm{~K}$ in calibrachoa $(P \leq 0.05)$. Initial percent $\mathrm{N}$ level in cuttings transplanted at location $\mathrm{F}$ and final percent $\mathrm{N}$ in locations $\mathrm{C}, \mathrm{E}, \mathrm{G}$, and $\mathrm{H}$ were below the mean -2 SD survey levels. Locations $\mathrm{E}, \mathrm{G}$, and $\mathrm{H}$ also had the three lowest total applied N. P levels were within the survey range, and final $\mathrm{K}$ level in location $\mathrm{C}$ was slightly below the mean $-2 \mathrm{SD}$. There was no correlation between change in DW and tissue percent of $\mathrm{N}, \mathrm{P}$, or $\mathrm{K}$. Substrate nutrients. The optimal EC range for greenhouse substrate using a saturated media extraction (SME) is 0.75 to 2.0 $\mathrm{mmho} / \mathrm{cm}$ for plugs (Styer and Koranski, 1997). According to Scoggins, the media squeeze (or press extraction method) averages 0.1 $\mathrm{d} S \cdot \mathrm{m}^{-1}$ higher than the SME method for petunia; therefore, a substrate-EC lower than 0.85 or higher than 2.6 is beyond the acceptable limit when performing a media squeeze in a petunia crop (Scoggins et al., 2002; Styer and Koranski, 1997). SubstrateEC at each location ranged from 0.2 to $3.2 \mathrm{dS} \cdot \mathrm{m}^{-1}$ during week $\mathrm{l} ; 0.4$ to $3.2 \mathrm{dS} \cdot \mathrm{m}^{-1}$ during week $2 ; 0.3$ to 1.4 $\mathrm{dS} \cdot \mathrm{m}^{-1}$ during week 3 ; and 0.4 to 2.3 $\mathrm{dS} \cdot \mathrm{m}^{-1}$ during week 4 (Table 3 ). On average, there was a significant decrease in substrate-EC in weeks 1,2 , and $3\left(2.0,1.32\right.$, and $0.80 \mathrm{dS} \cdot \mathrm{m}^{-1}$, respectively) with a rise in week 4 (Table 3). Substrate-EC during week 3 was below the acceptable limit (Styer and Koranski, 1997). Seven of the eight locations showed a significant drop in substrate-EC from week 1 to week 2 of propagation (Table 3 ). Most of the substrate-pH values were in an acceptable range (5.6 to 6.4; Argo and Fisher (2002)) and averaged 5.3 to 6.5 (data not shown). The $\mathrm{N}, \mathrm{P}$, and $\mathrm{K}$ content at the end of the 4 -week crop cycle varied widely (between 0.14 and $2.92 \mathrm{~g} \cdot \mathrm{m}^{-2} \mathrm{~N}$, 0.02 and $0.41 \mathrm{~g} \cdot \mathrm{m}^{-2} \mathrm{P}$, and $0.5 \mathrm{l}$ and $4.5 \mathrm{l} \mathrm{g} \cdot \mathrm{m}^{-2} \mathrm{~K}$; Table 4). The lowest substrate- $\mathrm{N}$ occurred in location $\mathrm{E}$, which also had the lowest growth, $\mathrm{N}$ tissue uptake, and leachate N (Table 4).

Leachate Nutrients. The leachate-EC during weeks $1,2,3$, and 4 averaged $2.77,1.50,0.89$, and $1.40 \mathrm{dS} \cdot \mathrm{m}^{-1}$, respectively (Table $3)$. In contrast, applied nutrient solution-EC increased over weeks 1 to 4 , suggesting that the high leachateEC in week 1 resulted primarily from leaching of the preplant nutrient charge. Based on the nutrient analysis results for the leachate samples, on average, locations leached $1.09 \mathrm{~g} \cdot \mathrm{m}^{-2}$ $\mathrm{N}, 0.27 \mathrm{~g} \cdot \mathrm{m}^{-2} \mathrm{P}$, and $1.52 \mathrm{~g} \cdot \mathrm{m}^{-2} \mathrm{~K}$ over the 4-week crop cycle (Table 4). 
Table 3. Nutrient solution applied over time at eight greenhouse locations ${ }^{\mathrm{z}}$.

\begin{tabular}{|c|c|c|c|c|c|c|c|}
\hline Location & $\begin{array}{l}\text { Crop age } \\
\text { (weeks) }\end{array}$ & $\begin{array}{c}\text { Irrigation } \\
\text { method }^{y}\end{array}$ & $\underset{\left(\mathrm{mg} \cdot \mathrm{L}^{-1}\right)^{\mathrm{x}}}{\text { Applied N }}$ & $\begin{array}{l}\text { Applied solution } \\
\text { EC }\left(\mathrm{d} S \cdot \mathrm{m}^{-1}\right)^{\mathrm{w}}\end{array}$ & $\begin{array}{c}\text { Substrate } \\
\text { EC }\left(\mathrm{dS} \cdot \mathrm{m}^{-1}\right)\end{array}$ & $\begin{array}{c}\text { Leachate } \\
\mathrm{EC}\left(\mathrm{dS} \cdot \mathrm{m}^{-1}\right)\end{array}$ & $\begin{array}{c}\text { Leach } \\
\operatorname{vol}(\mathrm{L})^{\mathrm{v}}\end{array}$ \\
\hline \multirow[t]{4}{*}{ A } & 1 & Boom & 80.2 & $0.7 \mathrm{a}^{\mathrm{u}}$ & $2.5 \mathrm{~b}$ & $2.7 \mathrm{~b}$ & $0.4 \mathrm{a}$ \\
\hline & 2 & Boom and hand & 145.7 & $1.2 \mathrm{c}$ & $3.2 \mathrm{c}$ & $3.2 \mathrm{~b}$ & $0.1 \mathrm{a}$ \\
\hline & 3 & Boom and hand & 139.3 & $1.1 \mathrm{c}$ & $0.6 \mathrm{a}$ & $0.8 \mathrm{a}$ & $0.1 \mathrm{a}$ \\
\hline & 4 & Boom and hand & 109.8 & $0.9 \mathrm{~b}$ & $0.4 \mathrm{a}$ & $0.3 \mathrm{a}$ & $0.4 \mathrm{a}$ \\
\hline \multirow[t]{2}{*}{ B } & 1 & Boom & 6.2 & $0.2 \mathrm{a}$ & $0.2 \mathrm{a}$ & $0.2 \mathrm{a}$ & $3.4 \mathrm{c}$ \\
\hline & 4 & Hand & 112.8 & $1.0 \mathrm{c}$ & $1.0 \mathrm{c}$ & $1.2 \mathrm{~b}$ & $1.0 \mathrm{~b}$ \\
\hline \multirow[t]{4}{*}{$\mathrm{C}$} & 1 & Boom & 67.8 & $0.9 \mathrm{a}$ & $1.8 \mathrm{~b}$ & $2.0 \mathrm{~b}$ & $0.9 \mathrm{~b}$ \\
\hline & 2 & Boom & 99.7 & $1.1 \mathrm{~b}$ & $1.3 \mathrm{a}$ & $1.5 \mathrm{bc}$ & $0.1 \mathrm{a}$ \\
\hline & 3 & Boom & 82.2 & $0.9 \mathrm{a}$ & $0.9 \mathrm{a}$ & $1.1 \mathrm{ac}$ & $0.8 \mathrm{~b}$ \\
\hline & 4 & Boom & 64.0 & $1.4 \mathrm{c}$ & $2.3 \mathrm{c}$ & $3.0 \mathrm{~d}$ & $0.4 \mathrm{a}$ \\
\hline $\mathrm{D}$ & 1 & Boom & 0.5 & $0.3 \mathrm{a}$ & $1.8 \mathrm{~b}$ & $3.4 \mathrm{c}$ & $0.4 \mathrm{~b}$ \\
\hline \multirow[t]{4}{*}{$\mathrm{E}$} & 1 & Boom & 0.4 & $0.3 \mathrm{a}$ & $3.2 \mathrm{~b}$ & $1.2 \mathrm{a}$ & $0.1 \mathrm{a}$ \\
\hline & 2 & Boom & 2.1 & $0.6 \mathrm{~b}$ & $0.7 \mathrm{a}$ & $1.0 \mathrm{a}$ & $0.7 \mathrm{~b}$ \\
\hline & 3 & Boom and hand & 93.5 & $0.8 \mathrm{c}$ & $1.0 \mathrm{a}$ & $0.9 \mathrm{a}$ & $0.1 \mathrm{a}$ \\
\hline & 4 & Boom and hand & 105.5 & $0.9 \mathrm{c}$ & $0.7 \mathrm{a}$ & $0.7 \mathrm{a}$ & $0.4 \mathrm{a}$ \\
\hline \multirow[t]{4}{*}{$\mathrm{F}$} & 1 & Boom & 5.0 & $0.3 \mathrm{a}$ & $3.1 \mathrm{c}$ & $4.8 \mathrm{c}$ & $0.3 \mathrm{~b}$ \\
\hline & 2 & Boom and hand & 0.0 & $0.2 \mathrm{a}$ & $2.5 \mathrm{~b}$ & $2.9 \mathrm{~b}$ & $0.0 \mathrm{a}$ \\
\hline & 3 & Hand & 52.4 & $0.5 \mathrm{c}$ & $1.4 \mathrm{a}$ & $1.7 \mathrm{a}$ & $1.2 \mathrm{c}$ \\
\hline & 4 & Hand & 72.7 & $0.7 \mathrm{~b}$ & $2.1 \mathrm{~b}$ & $2.0 \mathrm{a}$ & $0.5 \mathrm{~b}$ \\
\hline \multirow[t]{4}{*}{ G } & 1 & Mist & 6.8 & $0.4 \mathrm{a}$ & $0.9 \mathrm{bc}$ & $1.5 \mathrm{~b}$ & $1.4 \mathrm{c}$ \\
\hline & 2 & Mist & 11.7 & $0.5 \mathrm{a}$ & $0.4 \mathrm{a}$ & $0.4 \mathrm{a}$ & $0.4 \mathrm{~b}$ \\
\hline & 3 & Hand & 19.2 & $0.4 \mathrm{a}$ & $0.7 \mathrm{ab}$ & $0.5 \mathrm{a}$ & $0.0 \mathrm{a}$ \\
\hline & 4 & Hand & 107.4 & $1.1 \mathrm{~b}$ & $1.1 \mathrm{c}$ & $1.1 \mathrm{ab}$ & $0.1 \mathrm{ab}$ \\
\hline Avg & 3 & $\mathrm{~b}$ & 92.9 & $0.87 \mathrm{~b}$ & $0.80 \mathrm{c}$ & $0.89 \mathrm{a}$ & $0.36 \mathrm{a}$ \\
\hline Avg & 4 & $\mathrm{~b}$ & 101.0 & $1.01 \mathrm{c}$ & $1.32 \mathrm{~b}$ & $1.40 \mathrm{~b}$ & $0.46 \mathrm{ab}$ \\
\hline Avg & All & & 75.6 & 0.8 & 1.4 & 1.6 & 0.5 \\
\hline
\end{tabular}

${ }^{z}$ Data were analyzed by location (denoted $\mathrm{A}$ to $\left.\mathrm{H}\right)$ and crop age $(1,2,3$, and 4 weeks after sticking of cuttings).

${ }^{y}$ Irrigation method included boom, stationary mist, or hand-watering or a combination of more than one method during the same week.

${ }^{x}$ The applied nitrogen concentration was measured on one sample for each crop and location combined from five replicate irrigation collection funnels; $1 \mathrm{mg} \cdot \mathrm{L}^{-1}=1 \mathrm{ppm}$.

${ }^{w}$ Electrical conductivity (EC) data were based on five replicate samples per crop age and location; $1 \mathrm{dS} \cdot \mathrm{m}^{-1}=1 \mathrm{mmho} / \mathrm{cm}$.

${ }^{\mathrm{v}} \mathrm{l} \mathrm{L}=0.2642 \mathrm{gal}$.

"Mean separation used Tukey's honestly significant difference test at $P \leq 0.05$.

However, leaching levels at individual locations were as high as $1.81 \mathrm{~g} \cdot \mathrm{m}^{-2}$ $\mathrm{N}, 0.45 \mathrm{~g} \cdot \mathrm{m}^{-2} \mathrm{P}$, and $2.86 \mathrm{~g} \cdot \mathrm{m}^{-2} \mathrm{~K}$ or as low as $0.29 \mathrm{~g} \cdot \mathrm{m}^{-2} \mathrm{~N}, 0.11 \mathrm{~g} \cdot \mathrm{m}^{-2} \mathrm{P}$, and $0.76 \mathrm{~g} \cdot \mathrm{m}^{-2} \mathrm{~K}($ Table 4$)$.

\section{Compare nutrient use efficiency at each location}

The fate of nutrients applied during vegetative cutting propagation can be divided into tissue, substrate, and leachate. Tissue uptake was calculated by change in percent nutrient $\times$ DW from week 0 to week
4, and uptake efficiency was calculated from Eq. 4, in which $\mathrm{A}=$ tissue uptake. More efficient growers would be defined as having a high tissue uptake and low level of nutrients leached on both a percentage and absolute basis. On average, locations had $50 \% \mathrm{~N}, 49 \% \mathrm{P}$, and $46 \% \mathrm{~K}$ nutrient uptake efficiencies (Table 5) with individual locations up to $77 \% \mathrm{~N}, 72 \% \mathrm{P}$, and $73 \% \mathrm{~K}$ uptake efficiency. In terms of leachate, the average percent nutrients leached among locations ranged from 23\%
$\mathrm{N}, 34 \% \mathrm{P}$, and $28 \% \mathrm{~K}$ with maximum leaching levels of $45 \% \mathrm{~N}, 45 \% \mathrm{P}$, and $55 \% \mathrm{~K}$.

Several factors should be considered when evaluating the efficiency of nutrient management within an individual location. For example, location $\mathrm{E}$ had one of the higher nutrient uptake efficiencies (Table 5) and low nutrient leaching on a percentage (Table 5 ) and absolute (Table 4 ) basis along with moderate leached water volume (Table 2). However, location $\mathrm{E}$ also had excessively low tissue 
Table 4. Initial and final percent nitrogen $(N)$, phosphorus $(P)$, and potassium $(K)$ in the tissue ${ }^{z}$.

\begin{tabular}{|c|c|c|c|c|c|c|c|c|}
\hline Location $^{\mathrm{y}}$ & Species & \multicolumn{2}{|c|}{$\begin{array}{l}\text { Concn in } \\
\text { tissue (\%) }\end{array}$} & $\begin{array}{c}\text { Change } \\
\text { in } \mathrm{DW}^{\mathrm{x}} \\
\text { (g/cutting) }\end{array}$ & $\begin{array}{c}\text { Tissue } \\
\text { uptake }^{w} \\
\left(\mathrm{~g} \cdot \mathbf{m}^{-2}\right)\end{array}$ & $\begin{array}{c}\text { Final } \\
\text { substrate } \\
\text { nutrient }^{\mathrm{v}}\left(\mathrm{g} \cdot \mathrm{m}^{-2}\right)\end{array}$ & $\begin{array}{l}\text { Leached } \\
\text { nutrient }^{\mathbf{u}} \\
\left(\mathrm{g} \cdot \mathrm{m}^{-2}\right)\end{array}$ & $\begin{array}{c}\text { Total } \\
\text { applied } \\
\left(\mathrm{g} \cdot \mathbf{m}^{-2}\right)\end{array}$ \\
\hline \multicolumn{9}{|l|}{ Nitrogen } \\
\hline $\mathrm{B}$ & Calibrachoa & 3.9 & 3.8 & $0.07 \mathrm{e}$ & $1.7 \mathrm{ef}$ & 1.52 & $1.59 \mathrm{ab}$ & 4.8 \\
\hline $\mathrm{C}$ & Petunia & 4.8 & 3.6 & $0.10 \mathrm{cde}$ & $2.3 \mathrm{~cd}$ & 2.26 & $0.90 \mathrm{abc}$ & 5.4 \\
\hline $\mathrm{D}$ & Calibrachoa & 4.0 & 3.8 & $0.09 \mathrm{de}$ & $2.9 \mathrm{c}$ & 2.92 & $0.95 \mathrm{abc}$ & 6.8 \\
\hline $\mathrm{F}$ & Calibrachoa & 3.0 & 3.6 & $0.18 \mathrm{a}$ & $4.5 \mathrm{a}$ & 2.08 & $1.69 \mathrm{a}$ & 8.3 \\
\hline G & Calibrachoa & 5.4 & 2.3 & $0.11 \mathrm{~cd}$ & $1.3 \mathrm{f}$ & 1.57 & $0.73 \mathrm{bc}$ & 3.6 \\
\hline $\mathrm{H}$ & Calibrachoa & 4.6 & 3.2 & $0.12 \mathrm{bc}$ & $1.8 \mathrm{de}$ & 0.47 & $1.81 \mathrm{ab}$ & 4.0 \\
\hline Avg & & $4.5 \mathrm{a}$ & $3.4 \mathrm{~b}$ & 0.11 & 2.4 & 1.42 & 1.09 & 4.9 \\
\hline $\mathrm{SE}$ & & 0.12 & 0.12 & 0.01 & 0.1 & & 0.16 & \\
\hline $\mathrm{D}$ & Calibrachoa & 0.5 & 0.6 & & $0.5 \mathrm{bc}$ & 0.05 & $0.15 \mathrm{~b}$ & 0.7 \\
\hline $\mathrm{E}$ & Petunia & 0.5 & 0.6 & & $0.2 \mathrm{ef}$ & 0.10 & $0.15 \mathrm{~b}$ & 0.5 \\
\hline $\mathrm{F}$ & Calibrachoa & 0.4 & 0.5 & & $0.6 \mathrm{a}$ & 0.17 & $0.23 \mathrm{ab}$ & 1.0 \\
\hline G & Calibrachoa & 0.5 & 0.4 & & $0.3 \mathrm{de}$ & 0.17 & $0.36 \mathrm{ab}$ & 0.9 \\
\hline $\mathrm{H}$ & Calibrachoa & 0.7 & 0.5 & & $0.3 \mathrm{cde}$ & 0.18 & $0.38 \mathrm{ab}$ & 0.9 \\
\hline Avg & & $0.5 \mathrm{a}$ & $0.5 \mathrm{a}$ & & 0.4 & 0.14 & 0.27 & 0.8 \\
\hline $\mathrm{SE}$ & & 0.01 & 0.01 & & 0.2 & & 0.04 & \\
\hline \multicolumn{9}{|l|}{ Potassium } \\
\hline A & Petunia & 5.7 & 4.5 & & $4.1 \mathrm{~b}$ & 0.51 & $1.05 \mathrm{~b}$ & 5.7 \\
\hline $\mathrm{B}$ & Calibrachoa & 3.6 & 3.5 & & $1.6 \mathrm{~d}$ & 1.21 & $1.44 \mathrm{ab}$ & 4.3 \\
\hline SE & & 0.12 & 0.12 & & 0.2 & & 0.27 & \\
\hline
\end{tabular}

${ }^{2}$ Change in dry weight (DW) for each species at each location. N, P, and K applied and distribution in the tissue, substrate, and leachate at each location.

'Each letter (A to $\mathrm{H})$ represents an individual location.

xChange in dry weight (DW) per cutting was calculated by subtracting the DW at week 4 from the DW at week 0 .

w $1 \mathrm{~g} \cdot \mathrm{m}^{-2}=0.0033 \mathrm{oz} / \mathrm{ft}^{2}$; calculated by multiplying the dry weight of the vegetative cuttings at week 4 and week 0 by the percent $\mathrm{N}$, $\mathrm{P}$, or $\mathrm{K}$ at week 4 ("final" percent in tissue) and at week 0 ("initial" percent in tissue) and calculating the difference.

${ }^{v}$ Calculated by multiplying the $\mathrm{mg} \cdot \mathrm{L}^{-1} \mathrm{~N}, \mathrm{P}$, and $\mathrm{K}$ in the soil solution by the container capacity for each tray and then converting to $\mathrm{g} \cdot \mathrm{m}^{-2}$.

"Calculated by multiplying the $\mathrm{mg} \cdot \mathrm{L}^{-1} \mathrm{~N}, \mathrm{P}$, and $\mathrm{K}$ by the total volume of leachate over 4 weeks.

tThe sum of the tissue uptake, nutrients leached, and final substrate nutrient content. Mean separation used Tukey's honestly significant difference test $(P \leq 0.05)$.

percent $\mathrm{N}$ and low growth rate (Table 4) suggesting that inadequate $\mathrm{N}$ fertilizer was applied.

\section{Conclusion}

The variability in water and fertilizer use, and our observation that liners produced at all locations were saleable plant material, indicates that there is a broad range in practices and resource efficiencies that can be used to produce a horticulturally acceptable product. That situation presents an educational opportunity (to improve efficiency) by minimizing leaching and optimizing uptake and a challenge to convince growers of a need for change when current practices are already producing acceptable crops. We attribute management differences to grower decisions and technology rather than to differing geographic locations, because locations with similar greenhouse temperature and structures located only 10 $\mathrm{km}$ apart leached very different water levels. In follow-up discussions with the grower businesses in this study, these leaching and fertilizer data were helpful as a training tool and baseline to review practices that could minimize leaching and more closely match water and nutrient supply with plant need. Examples of management practices operations with high leaching rates implemented were to reduce the irrigation frequency during early propagation stages or to replace old mist nozzles with nozzles that supply smaller volumes of water. Further research should focus on optimizing strategies to supply necessary nutrients and water during the root initiation and growth stages and to measure the impact of 
Table 5. Nitrogen, phosphorus, and potassium use efficiency for each location.

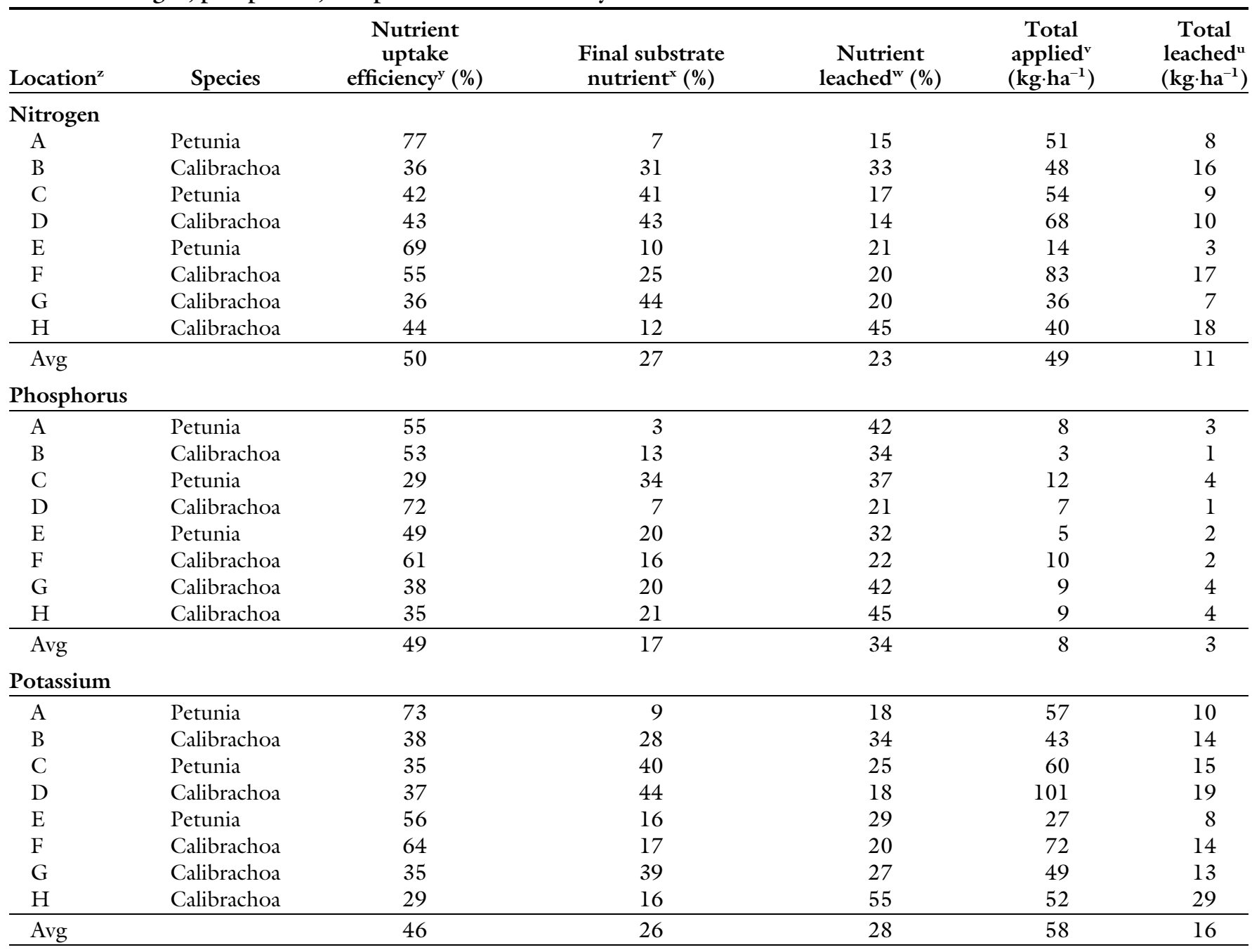

${ }^{\mathrm{z}}$ Each letter (A to $\mathrm{H}$ ) represents an individual location.

yThe percent nutrient uptake (also termed uptake efficiency) was calculated by dividing the total $\mathrm{mg} /$ tray (Table 4 ) by the change in tissue dry weight in milligrams (Table 4 ).

x The final percent nutrient in substrate was calculated by dividing the total $\mathrm{mg} /$ tray (Table 4 ) by the final substrate nutrient concentration (Table 4 ).

whe percent nutrient leached was calculated by dividing the total $\mathrm{mg}$ applied/tray (Table 4) by the nutrients leached in milligrams (Table 4 ).

${ }^{\mathrm{v}} \mathrm{l} \mathrm{kg} \cdot \mathrm{ha}^{-1}=0.8922 \mathrm{lb} /$ acre; calculated by converting the total $\mathrm{mg} /$ tray to $\mathrm{kg} \cdot \mathrm{ha}^{-1}$

"Calculated by converting the total $\mathrm{mg} /$ tray to $\mathrm{kg} \cdot \mathrm{ha}^{-1}$.

grower training on improved resource efficiency.

\section{Literature cited}

Argo, W.R. and J.A. Biernbaum. 1996. Availability and persistence of macronutrients from lime and preplant nutrient charge fertilizers in peat-based root media. J. Amer. Soc. Hort. Sci. 121: $453-460$.

Argo, W.R. and P.R. Fisher. 2002. Understanding $\mathrm{pH}$ management for container-grown crops. Ist Ed. Meister, Willoughby, OH.

Biernbaum, J.A., W.R. Argo, B. Weesies, A. Weesies, and K. Haack. 1995. Persistence and replacement of preplant nutrient charge fertilizers from highly leached peat-based root media. HortScience 30:763 (abstr.).
Blazich, F.A. 1988. Mineral nutrition and adventitious rooting, p. 61-69. In: David, T.D. B.E. Haissing, and N. Sankhla (eds.). Adventitious root formation in cuttings. Dioscorides Press, Portland, OR.

Dole, J.M. and J.L. Gibson. 2006. Cutting propagation: A guide to propagating and producing floriculture crops. lst Ed. Ball Publishing, Batavia, IL.

Geneve, R., R. Gates, S. Zolnier, E. Wilkerson, and S. Kester. 2004. Environmental control systems for mist propagation of cuttings. Acta Hort. 630:297301 .

Gibson, J.L. 2003. Influence of mineral nutrition on stock plant yield and subsequent rooting of stem cuttings of scaevola, new guinea impatiens, and vegetative strawflower. North Carolina State University, Raleigh, NC. PhD Diss.
Groves, K.M., S.L. Warren, and T.E. Bilderback. 1998. Irrigation volume, application, and controlled-release fertilizer. II. Effect on substrate solution nutrient concentration and water efficiency in containerized plant production. J. Environ. Hort. 16:182-188.

Kerr, G.P. and J.J. Hanan. 1985. Leaching of container media. J. Amer. Soc. Hort. Sci. 110:474-480.

$\mathrm{Ku}$, C.S.M. and D.R. Hershey. 1997. Growth response, nutrient leaching, and mass balance for potted poinsettia. I. Nitrogen. J. Amer. Soc. Hort. Sci. 122: $452-458$.

Lebude, A., V.B. Goldfar, F. Blazich, F. Wise, and J. Frampton. 2004. Mist, substrate water potential and cutting water potential influence rooting of stem cuttings of loblolly pine. Tree Physiol. 24: 823-831. 


\section{Research Reports}

McAvoy, R.J., M.H. Brand, E.G. Corbett, J.W. Bartok, Jr., and A. Botacchi. 1992. Effect of leachate fraction on nitrate loading to the soil profile underlying a greenhouse crop. J. Environ. Hort. 10:167-171.

Nelson, P.V. 1998. Greenhouse operations and management. 5th Ed. Prentice Hall, Englewood Cliffs, NJ.

Nelson, P.V. 1990. Developing root zone management strategies to minimize water and fertilizer waste: The United States perspective with emphasis on surface applied, nonrecirculating systems. Acta Hort. 272:175-184.

Rowe, D.B. and F.A. Blazich. 1999. Mineral nutrient and carbohydrate status of loblolly pine during mist propaga- tion as influenced by stock plant nitrogen fertility. HortScience 34:12791285 .

Schaible, G.D. and M.P. Aillery. 2003. Irrigation technology transitions in the mid-plains states: Implications for water conservation/water quality goals and institutional changes. Int. J. Water Resour. Dev. 19:67-88.

Scoggins, H.L., D.A. Bailey, and P.V. Nelson. 2002. Efficacy of the press extraction method for bedding plant plug nutrient monitoring. HortScience 37:108-112.

Styer, R.C. and D.S. Koranski. 1997. Plug and transplant production-A grower's guide. Ball Publishing, Batavia, IL.
U.S. Department of Agriculture. 2006. Agricultural statistics for 2005. U.S. Dept. Agr., Washington, D.C.

Weibe, K. and N. Gollehon. (eds.). 2006. Irrigation resources and water costs. 26 July 2006.<http://www.ers.usda.gov/publications/arei/eibl6/Chapter2/2.1/>.

Yelanich, M.V. and J.A. Biernbaum. 1993. Root-medium nutrient concentration and growth of poinsettia at three fertilizer concentrations and four leaching fractions. J. Amer. Soc. Hort. Sci. 118:771-776.

Yelanich, M.V. and J.A. Biernbaum. 1994. Fertilizer concentration and leaching affect nitrate-nitrogen leaching from potted poinsettia. HortScience 28:874-875. 